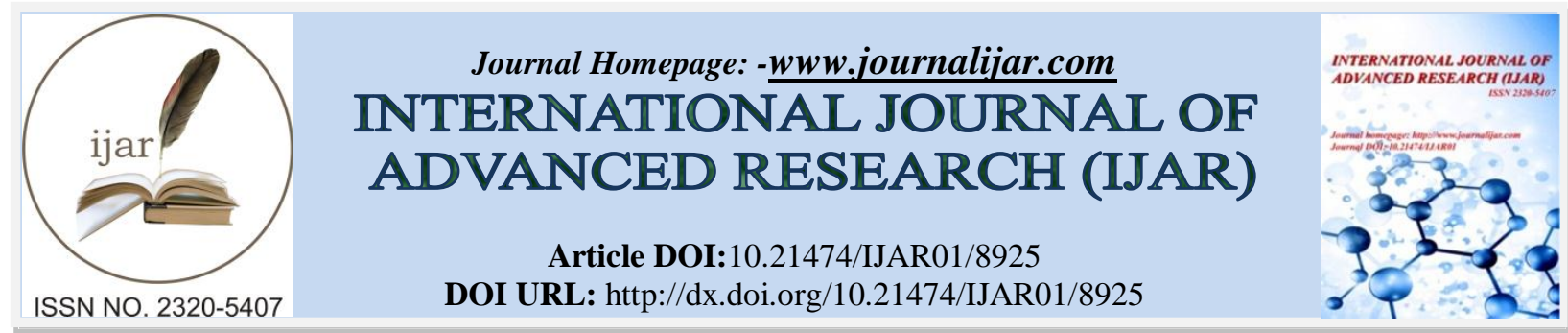

RESEARCH ARTICLE

\title{
SCIENTIFIC PERSPECTIVE ON MORPHOLOGICAL FEATURE OF PECTEN OCULI AND THEIR FUNCTIONAL PRINCIPLES ON APPARATUS OF VISION IN GUINEA FOWL (NUMIDA MELEAGRIS) BIRDS.
}

Pratiksha Mishra and Balwant Meshram.

Department of Veterinary Anatomy and Histology, College of Veterinary and Animal science, Navania, Udaipur Rajasthan, India-313601.

\section{Manuscript Info}

\section{Manuscript History}

Received: 21 February 2019

Final Accepted: 23 March 2019

Published: April 2019

Key words:-

Guinea fowl (Numida meleagris), Pecten oculi, Blood capillaries, Immunity, Nucleated erythrocyte, Spring diving board, Accordion folds, Histomorphology, Ultrastructure.

\begin{abstract}
The study was conducted on 18 eyes, which revealed that dark black velvety pecten oculi has 13 to 17 number of accordion (pectineal) folds. These accordion folds were initiated from cauda of optic nerve and travelled via fundus distally into the vitreous humour in the manner of undulated natured pathway of snake. Macroscopically the shape of pecten oculi was observed without much difference of the sail board. The maximum average length and height of pecten oculi was found on the tune of $3.378 \pm 0.061 \mathrm{~mm}$ and $5.913 \pm 0.074 \mathrm{~mm}$ respectively. Histomorphologically the pecten oculi showed an organization as the festoon of blood capillaries with their elastic, collagen and reticular fibers which correspond with the structure of spring diving board. Its working principle was also being matched with Hook's law, how the diving spring board work. Melanocytes, melanosomes and melanin granules were observed in and around blood capillaries of pecten oculi. The highest concentration of melanin was observed in the apex. Histochemically the pecten oculi was shown very weak activity of acid phosphatase and alkaline phosphatase. It has shown a strong activity of glycogen at optic nerve and collagen fibers of pectineal capillaries. Ultrastructurally, the nucleated erythrocytes were witnessed at luminal area of pectineal blood capillary and the endothelium was elaborating tight intercellular junction. The primary and secondary lamellae were observed in the luminal region of pectineal capillary wherein pigment depositing globules were discovered. Pecten oculi of Guinea fowl (Numida meleagris) perform various functions, after which it is identified as the organ of haemostatic function, support system to retina to get visual acuity, phagocytic, immunity shield and the source of energy for vitreous humour by performing process of diffusion.
\end{abstract}

Copy Right, IJAR, 2019,. All rights reserved.

\section{Introduction:-}

Though there are the several components which work all together to have the functional eyes in birds, but a comb like distinctive structure of pecten oculi specifically found in avian eye. It plays a very crucial role in the 
functioning principles of optic globe. The highly vascular and pigmented pecten oculi has a vital role in the functioning of eye. It provides nutrition to retina after the retinal circulation, regulate intraocular pressure $\&$ the $\mathrm{pH}$ and also it endow oxygen gradient to retina (Wingstrand and Munk, 1965). It also functions in maintaining the acid base balance and constant intraocular temperature (Brach, 1975, 1977). Plenty of pigment cells are located there in pecten oculi which performs to perform as the functional ability while absorbing the heat and thereby it also functions as the organ of homeostasis (Bawa and Roy, 1974).

The shapes of pecten oculi have been classified morphologically as Conical, Vaned and Pleated types. The conical pecten was observed in kiwi (Apteryx mantel), vaned type was observed in ostrich (Struthio camelus) and rhea (Rhea americana) and pleated type of pecten was observed in few species of birds like quail, common buzzard, black kite, galah etc. (Meyer, 1977, Orhan et al., 2011 and Braekvelt 1984). The variations in size and number of folds in pecten oculi are observed in diurnal and nocturnal bird (Braekvelt 1988, Dayan and Ozaydin 2013).

The pecten oculi in Guinea fowl (Numida meleagris) birds have revealed in analogous shape of the sail board. Microscopically it has shown the close resemblance with a structural model of diving spring board, the machine of specialty used as water diving sport device. Diving springboard and its mechanical integral elements were discussed by Miller (2008), Barris (2013) and Sprinings (1990) which have shown very close resemblance with the observed morphological components of pecten oculi. The discovered structural components of pecten oculi have shown their contribution in maintaining the natural performance of apparatus of vision. Therefore, present studies of pecten oculi in Guinea fowl (Numida meleagris) are undertaken for scientific delineation of its histomorohological, functional and ultrastructural strictures and thereby the functioning principle of them.

\section{Material \& Method:-}

The samples of Pecten oculi were collected from 09 head counts of adult Guinea Fowl (Numida meleagris) birds. The heads were collected at pre-identified commercial slaughtering units without any account of record of their sex and it was carried to the laboratory on ice. Immediately after reaching to the laboratory, eyes were enucleated very carefully from the orbit for further routine investigative procedure.

Initially samples of pecten oculi were collected by equatorial dissection of the apparatus of vision and it was subjected for the studies of morphology structures as per Orhan et al. (2011) and Dayan and Ozaydin (2013). During the dissection of eye it was observed that, while taking a cut equatorially on eyeball the delicate components of pecten were getting smashed off (Fig. 1). It were getting partly distributed in both the half by forceful movement of vitreous while getting it drain hence kept the complete enucleated eye ball into refrigerator for 2 minutes as to refrigerate vitreous to restrain its movement and thereby to find stand firm pecten with every delicate component.

In the later stage while dissecting the eyes preferred an elliptical cut around a striped type of scar mark identified at sclera, the outermost tunic, in a mediodorsal position of eyeball. It was also discovered that the scar mark was there due to striped shaped position of optic disc inside the eyeball. After collecting pecten it was preceded for studies of the morphology structure. The collected specimens of pecten oculi were studied and its findings were recorded on the parameter of its location, orientation, attachment, color, number of accordion folds and their biometrical dimensions. Micrometrical observations were recorded with help of vernier caliper i.e. digimatic micrometer (MDCSX) of Mitutoya company.

After performing morphological studies, the collected samples were transferred in capsule for histomorphology as per Singh and Sulochana (1996). The paraffin sections were stained by Haematoxylin and Eosin method for general microscopical findings, Van Geison's stain method were employed for investigating the presence of collagen fibers and Azan Trichrome method as per Singh and Sulochana (1996) was used to explore the presence of collagen and Reticular fibers.

The biological samples were fixed for 24 hours in chilled acetone while performing histochemical investigations. Alkaline and acid phosphatase detection was done in accordance to the Gomori's method as per Singh and Sulochana (1996). McManu's method for PAS was used to identify the presence of glycogen and Fontana Masson Silver Method has been used to detect the presence of melanin. Stained slides were studied for microscopical and micrometrical observations. 
While pursuing the transmission electron microscopical (TEM) studies, 05 tissues samples were processed at Sophisticated Analytical Instrumentation Facility (SAIF), AIIMS, New Delhi The routine process was adopted while preparing the sections. The suitability of sections for TEM was ascertained after scrutinizing the sections under light microscope. The selection was accomplished for the area to be examined under transmission electron microscopy (TEM). The ultrathin sections of 60 to $150 \mathrm{~nm}$ thickness were taken with fresh glass knife and allowed to flow on the liquid of knife-boat and depending upon intrusion of colors shown by the ultrathin sections their thickness were determined. Generally they were shown Gray, Silver and Golden color. The Gray colored ultrathin sections had thickness of $60 \mathrm{~nm}$, silver with 60 to $90 \mathrm{~nm}$ and gold has 90 to $150 \mathrm{~nm}$ thickness. As golden colored sections were suitable for low magnification studies, it was stretched by exposing to chloroform. The sections were lifted over matted surface of grid and were allowed them to stick firmly there. Double staining method was applied by using uranyl acetate and alkaline lead citrate to achieve the suitable contrast and sections were studied at various magnifications under transmission electron microscope (TEM).

\section{Results:- Morphological Studies}

The morphological features of the pecten were studied thoroughly and noticed that dark black pigmented structure in velvety consistency was found initiated from the cauda of optic nerve and travels via fundus distally into the vitreous humour. The basal border of pecten has shown attachment to the head of stripe shaped optic disc which known to be the base of pecten. When the pecten oculi leaves a striped shaped optic disc it shows similarity in shape of sailboard, which works as the windsurfing-floating unit of it used for gliding on water (Fig 2).

It has shown pleural 13 to 17 number of accordion viz. pectineal folds with bilateral attachment to the adjoining folds. A band of pectineal folds was started from the base and moved vertically inward into vitreous which was recognized as the bridge. It was determined as the pleated type of pecten oculi due to their cohesive structure formed with alternate furrow and bulging which were similarly interconnected by intercostal muscles of body cage formed by ribs in animals.

The maximum length of base in all the 18 numbers of pecten oculi was measured and it was in the range of 3.865 to $2.899 \mathrm{~mm}$, with an average of $3.378 \pm 0.061 \mathrm{~mm}$. Maximum height of pecten was measured from its attachment at optic disc, from where it was initiated, to the distal end of bridge and it was found in between the range of 6.339 to 5.248, with an average of $5.913 \pm 0.074 \mathrm{~mm}$ (Table. 1).

\section{Histomorphological Observations}

The histomorphological slides were stained with different stains as to Haematoxylin and Eosin, Van Geison's, Azan Trichrome and Toluidine Blue after which it were studied under light microscope on different magnifications. Micrometrical observations of the pecten oculi were recorded with the help of ocular micrometrical appliances.

Microscopically the pecten oculi has shown an emergence from the core of optic nerve and got progression as the festoon of blood capillaries in varied shape at posterior side upto half way inside of the cup of eyeball. The anterior end of pecten oculi was a cohesive structured with optic nerve at ventral part of optic disc while its posterior end was located into the vitreous humour. At the anterior end of the summit of pecten and optic nerve the pleural numbers of prominent blood capillaries were also identified with either side retinal layers (Fig. 3). The free posterior end of pecten oculi was obtained with cantilever fashioned triangular shaped structure which known as the bridge (Fig. 4). The total length of pecten oculi, which was initiated at optic disc measured up to the distal end of bridge that was discovered between 298 to $462 \mu \mathrm{m}$, which was calculated with an average of $379.500 \pm 13.445 \mu \mathrm{m}$ (Table. 1).

The centrally positioned bulbous structured optic nerve was invariably found with the either side placed combine layers of choroid and sclera. Connective tissue at the outer side of scleral tunic, scleral ossicles, hyaline cartilage, the vascular tunic of choroid, pecten oculi, retinal layers and accordion folds were very well identified (Fig. 3).

Medium shaped choroidal blood vessels were perceived with the lining of flattened type of endothelial wall. Adventitia was also well defined and embedded in areolar connective tissue network wherein few melanocytes were observed. The smaller melanin granules were there but it was supportive to the overall function of pecten. The complete pecten oculi from optic nerve to the distal end of bridge tentatively distributed into three equal portions 
viz. bridge, base and middle one third (Fig. 5). The middle one third has shown maximum length of the accordion folds and it was recorded between 46 to $94 \mu \mathrm{m}$ with an average of $62.556 \pm 3.335 \mu \mathrm{m}$.

Accordion folds also called as pectineal folds, started its journey from base and travels to hold apex, the bridge, which tracks the way as to lateral undulation type of movement, the similarly fashioned movement of snake. Every of the accordion folds was showing numbers of blood capillaries with variable sized diameter but in most of the cases larger dimension of capillaries were only located at the middle one third of pecten and in particular the central linear component of the pecten has largest most dimension of blood capillaries (Fig. 6). These capillaries with larger dimension which were located at the middle one third of pecten oculi were recorded in the range of 4 to $14 \mu \mathrm{m}$ with its average $7.722 \pm 0.641 \mu \mathrm{m}$ (Table. 1).

The distance between two pectineal folds were also found on higher tune at the same middle one third virtual portion of pecten which was recorded between 9 to $13 \mu \mathrm{m}$ and its average was $11.167 \pm 0.316 \mu \mathrm{m}$. The maximum luminal diameter of blood capillary among the various pectineal folds of pecten oculi was noted in between the range of 5 to $12 \mu \mathrm{m}$ with the findings of its average $7.833 \pm 0.601 \mu \mathrm{m}$ (Table. 1).

The pectineal folds have shown the complex association of blood capillaries with varied density and shape (Fig. 7 and 8). It was not only showing the presence of nucleated erythrocytes but also it was showing the distinct distribution of heterophils, monocytes and even thrombocytes too. The pectineal blood capillaries were shown tight junctions at luminal surface by the endothelial cells, which has the thickest nuclear region. These vessels have also shown the thick basal lamina wherein the pericytes were found enclosed (Fig. 9).

The pecten oculi has shown over all dark black coloration due to the aggregated melanosomes which was surfaced at luminal and abluminal component of pectineal blood capillaries. Deliberation of the melanin observed highest in concentration at apex, the bridge and even in the laterally placed undulated fold components of pecten. The polymorphic melanocytes were unmistakably revealed its presence individually or in groups at inside and outside of the blood vessels, in between different blood vessels. Hyalocytes, the vitreous cells were also observed in particular at the convex and concave surface of accordion folds (Fig. 10).

\section{Histochemical Findings}

Alkaline phosphatase

The pecten oculi has shown a very weak activity of alkaline phosphatase in the form of extreme slight blackish color at the structure components which contribute at the pectineal capillaries. The basal lamina and the endothelial cells have also exhibited the equal strength of activity and it was very weak (Fig. 11).

\section{Acid Phosphatase}

Pecten oculi, the festoon of blood capillaries has demonstrated the extreme weak activity by way of inconsiderable black color at the endothelial and basal lamina region. Even this activity of acid phosphatase, what has exhibited was very much weak than the alkaline phosphatase (Fig. 12).

\section{Periodic-Acid-Schiff (PAS) for Glycogen}

The accordion fold of pecten oculi which was holding the optic nerve as its base and that was travelling inside distally into the vitreous humour has shown strong activity of glycogen at optic nerve and at the collagen fibres which were forming the structure of pectineal capillaries. The strong red-purple color was noticed at both endothelial and basal lamina region of capillary. Even it has show off the strongest presence of activity of glycogen at connective tissue septa which surrounds the apex of pecten which known as the Bridge (Fig. 5 and 13).

\section{Fontana-Masson Silver for Melanin}

The pecten oculi was showing the intense higher concentration of positive reaction for melanin at the capillaries which was surrounding the triangular apex, known as the bridge. The similar higher degree of reaction at pigmented epithelium of retinal layer was also observed. The reaction was also seen at laterally placed blood capillaries of undulated fold components of pecten (Fig. 14).

\section{Transmission Electron Microscopical Findings}

Transmission Electron Microscopy (TEM) has been used to determine the ultrastructural details pf pecten oculi. The luminal portion of pectineal blood capillary has shown the nucleated erythrocytes (Fig. 15). The endothelial cells of 
the capillary were elaborating tight junction between basement membrane. The pectineal capillary was illustrating the pericytes with prominently thickened portion of basal lamina and the processes of melanocytes and melanosomes. The lumen of capillary has not only revealed the presence of heterophil but also it has shown the nucleated erythrocytes, which was surrounded by primary lamellae and the extra vascular pigment deposits, that were getting at the outside of capillary (Fig. 16 and 19).

Primary and secondary lamellae were getting at luminal surface of the pectineal capillary. Secondary lamellae were showing an expansion as to tertiary into vacant luminal place and the nucleus (Fig. 17). Pigment deposition was spotted at primary lamellae and nucleus was located at centre. The primary lamellae were placed at centre, which leads to secondary lamellae. Pigment depositing globules were discovered in primary lamellae with centrally placed nuclei. The secondary lamellae at luminal component have shown the melanin pigment depositing globules (Fig. 18).

\section{Discussion:-}

In the macro and micro morphological studies of Pecten oculi in Guinea fowl (Numida meleagris) birds, the functional abilities and its working principle was accomplished after its thorough studies. The dark black pigmented structure in velvety consistency was discovered as the pecten oculi in eye ball that was initiated from the cauda of optic nerve and travel via fundus distally into the vitreous humour. The present findings were in agreement in totality with the findings mentioned by several researchers in different species of birds as to Mann (1924) in domestic hen (Gallus domesticus), Kiama et al. (2001) in nocturnal spotted eagle owl (Bubo bubo africanus), diurnal black kite (Milvus migrans) and domestic fowl (Gallus gallus var domesticus), Venkatesan and Ramesh (2006) in domestic fowl, Pourlis (2013) in quail (coturnix coturnix Japonica), Haller et al. (2014) in budgerigras (Melopsittacus undulatus) with collaborative observations.

All the 18 samples in the present study were endorsed the discovery of 13 to 17 number of accordion (pectineal) folds. Each of the fold had bilateral attachment with adjoining folds as the intercostal muscles between two ribs in animals and these annotations were similar to which specified by Tucker (1975) who has revealed his studies in pecten oculi of pigeon. Various studies of pecten in aves has been reported with variable number of folds as Onuk et al. (2013) have reported 15-17 folds in stork (Ciconia ciconia), Braekevelt (1993) in great horned owl (Bubo virginianus) has recorded 7-8 folds, Orhan et al. (2011) in quail (Coturnix coturnix japonica) were recorded 19 folds and Pourlis (2013) in quail (Coturnix coturnix japonica) has reported the number of pectineal folds in a range of 1822. Micali et al.(2012) were differentiated the birds as day active viz. diurnal, which has more than 10 pleats and night active viz. nocturnal, which has pleats within the range of 4-5. A day and night active bird has higher and decreased visual acuity respectively which was reliant upon the number of pleats possessed by pecten oculi. In view of that well said differentiation the bird Guinea fowl (Numida meleagris) upon which present study was performed has comfortably confirmed as the diurnal bird and its habit while getting the prey was also showing the long establishment with the confirmation.

Base of the pecten had attachment dorsally to the head of stripe shaped optic disc and ventrally it moved off vertically inward by way of fundus into the vitreous humour. The different pectineal folds were formed a cohesive structure in vitreous humour as the apex, in the form of band which distinguished its entity as the bridge. The observations which has been observed in present studies were not different than the Braekevelt (1993) and confirmed that the pecten what we observed was nothing but the pleated type of pecten which has also been consented by Pourlis (2013). In his study of diurnal and nocturnal birds of various species he was mentioned that pleated pecten was widespread and essentially similar in most species. The presently studied pecten oculi which left the optic disc as a base and reach at the bridge with its either boundaries of temporal and nasal area has show off the shape of sailboard and functionally it was similar with windsurfing floating unit which glide on water.

The maximum length of base in presently studied pecten oculi has exhibited the range of 3.865 to $2.899 \mathrm{~mm}$ with an average of $3.378 \pm 0.061 \mathrm{~mm}$, while its maximum height from the initiation of optic disc to the bridge was also measured and it was in the range of 6.339 to $5.248 \mathrm{~mm}$, with an average of $5.913 \pm 0.074 \mathrm{~mm}$. The results in present study for base and height of pecten oculi were not collaborative with other species as reported by various researchers. Onuk et al. (2013) has reported the length $10.05 \pm 62.19 \mathrm{~mm}$ and height $5.53 \pm 1.11 \mathrm{~mm}$ in the pecten oculi of stork (Ciconia ciconia) and Pourlis (2013) in quail (Coturnix coturnix japonica) has measured the length and height $4-5 \mathrm{~mm}$ and $1 \mathrm{~mm}$ respectively. Though the observations were not collaborative with Onuk et al. (2013) 
as the figures but the proportion shown by them in respect of height and length of pecten oculi was similar with the present proportionate findings against height and length.

In this attempt of studies of pecten oculi it was cited as the crown at bulging of optic nerve which was invariably brought into being centrally positioned with its either side the sclera and choroid layer. Connective tissue at the outer side of scleral tunic, scleral ossicles, hyaline cartilage, vascular tunic of choroid, retinal layers and the components of accordion folds were very well identified under microscope. This outcome of the present examination was in accordance to the close consent of Jezler et al. (2010) what they observed in striped owl, Dayan and Ozaydin (2013) detected in different avian species and Onuk et al. (2013) in the stork (Ciconia ciconia).

Microscopically the core of optic nerve allows the pecten oculi to initiate and to pass through a vitreous humour, furthermore, at distal free end a cantilever fashioned irregularly triangular shaped structure was obtained which got acceptance in the name of bridge. The findings in the present study were not different than the Braekevelt (1984) and Venkatesan and Ramesh (2006) but it was very true that the initiation and end of pecten oculi has the connectivity by laterally undulated natured pathway of accordion (pectineal) folds, the similarly fashioned movement of snake.

The total length of pecten oculi from optic disc to the distal end of bridge was ascertained between 298 to $462 \mu \mathrm{m}$ with an average of $379.500 \pm 13.445 \mu \mathrm{m}$. On virtual three equal distribution of complete pecten oculi, the middle one third segments has shown the maximum length of accordion folds and it was recorded between 46 to $94 \mu \mathrm{m}$ with an average of $62.556 \pm 3.335 \mu \mathrm{m}$. Numbers of blood capillaries with varied diameter were noticed as the festoon at pecten oculi but in most of the cases not only the larger capillaries of remarkable dimensions were observed at the middle one third segment of pecten but the space between two pectineal folds were also observed on higher tune at this segment which was evidenced between 9 to $13 \mu \mathrm{m}$ with an average of $11.167 \pm 0.316 \mu \mathrm{m}$. These findings were recorded without any equality with the observations of other researchers as due to the non-availability of such micrometrical observations. Among the various positions of pectineal folds the maximum luminal diameter of their blood capillary was noted in the range of 5 to $12 \mu \mathrm{m}$ with its average $7.833 \pm 0.601 \mu \mathrm{m}$ which has much minimized dimension in relation to the recordings noted by Gultiken et al.(2012) in common buzzard (Buteo buteo) with 30 to $40 \mu \mathrm{m}$. Such dissimilarity may be recorded due to the species difference.

In addition, the central linear component of the middle one third of pecten oculi has brought to light the largest most dimensions of blood capillaries which were recorded in the range of 4 to $14 \mu \mathrm{m}$ with its average $7.722 \pm 0.641 \mu \mathrm{m}$.

The pecten oculi as a whole has exposed in a structure of varied shaped festoon of blood capillaries. Prominent blood capillaries were identified at the anterior end of unification of summit of pecten and optic nerve where retinal layers were located either side. Flattened type of endothelial wall lining was sited at the medium shaped choroidal blood vessels. Their adventitial layer was well defined and has got surrounded in areolar connective tissue network wherein few melanocytes were also observed. The smaller melanin granules were there but its presence was showing the supportiveness towards overall function of the pecten. These findings were identical to the findings of Mann (1924) who was observed the pecten oculi without restrictions of species, Bawa and Roy (1974) in the pecten of vulture, Kiama et al. (1994) who had observed the pecten oculi in black kite and Rajab (2012) in Sparrow Hawk (Accipiter nisus).

The retinal epithelium was discovered after single cell layer wherein the melanin pigments were packed. The adventitial layer was also there as the supporting structure to epithelial layer, in combine that function as outer barrier for retina while supporting its function for capturing the image. Moreover, the retina of Guinea fowl dissimilarly resembled with mammals as it was devoid of blood vessels, might be it was compensating by festoon of blood capillaries as the pecten oculi. These pectineal blood capillaries have tight junctions at luminal surface by the endothelial cells where it forms another barrier at inner side between retina and pecten oculi. The blood or fluid retinal barrier from either side, as outer and inner might be attributed to the sustaining system of retina for its normal functioning of image capture to get the visual acuity. These elucidations were in partly agreement with Cunha-Vaz (1976) as he had studied the blood retina barrier to know the pathophysiology and therapeutics of retinal diseases but without specifying of any species of animals or birds.

Pectineal folds have been profoundly shown the varied density and shape of blood capillaries. The nucleated erythrocytes were had evidenced there but the distinct distribution of heterophils, monocytes and even thrombocyte 
were also been demonstrated. The detection of erythrocytes at luminal component of pectineal capillary was the common feature by researchers as Bawa and Roy (1974) in vulture and Onuk et al. (2013) in stork but the other constituents of blood viz. heterophil, monocytes and thrombocyte were not reported earlier. Such presence has shown the significance of pecten oculi which perform for fight off diseases and infection by heterophils, phagocytosis by monocytes and hemostasis by the thrombocytes.

The luminal surface of these pectineal blood capillaries had tightly interconnected endothelial cells with its substantial prominent nuclear region. The pericytes has shown its existence which were surrounded by the thick basal lamina. The present detection at pectineal capillaries has similarity in observations as per Bawa and Roy (1974) in vulture pecten and Braekevelt (1993) in great horned owl.

In toto it has been observed that the pecten oculi has taken its dark black colour due to the melanosomes and it was surfaced at luminal and abluminal component of pectineal blood capillaries. The apex of the pecten oculi which also known as the bridge was observed with highest in concentration of melanin and same findings has also been shown at laterally positioned undulated fold components of pecten. In between pectineal blood vessels the polymorphic melanocytes were unquestionably revealed its presence either alone or in groups at inside and outside of the blood vessels. Hyalocytes, the vitreous cells were observed at the convex and concave surfaces of accordion folds. Similar findings have been put on record in the pecten oculi of most of the species by Braekevelt (1993) in great horned owl, Llombart et al. (2009) in quail, Rajab (2012) in sparrow hawk, Dayan and Ozaydin (2013) in different avian species and Onuk et al. (2013) in stork. In accordance to the principle of physics, black body absorbs the heat of those radiations of all wave length which fall on it. Melanosomes which was providing the black color to the pecten oculi through its different components, overall helps in absorbing that heat. It not only catalyzes the increase of metabolic reaction of pecten but also it tries to maintain the required elevated body temperature in the form of energy for birds as per the higher basal metabolic rate of the body of birds.

Ultrasructurally, the nucleated erythrocytes were witnessed at luminal area of pectineal blood capillary and the endothelial cells of capillary were elaborating tight junction between the basement membrane. The thick basal lamina of pectineal capillary has demonstrated pericytes and the processes of melanocytes and melanosomes. The capillary had nucleated erythrocytes in its lumen that were surrounded by primary lamellae with extra vascular pigment deposits at the capillary abluminally. Transmission electron microscopically the observations which were confirmed in the present study of pecten oculi in Guinea fowl (Numida meleagris) were presented collaboratively with the findings of Bawa and Roy (1974) and Braekevelt (1993) who were studied the pecten oculi in vulture and great horned owl respectively. But, in the present findings lumen of pectineal capillary has shown the presence of heterophils. In accordance to the WikiVet (2017) the heterophils, the similar constituent blood cells in mammal which known as the neutrophils or neurocytes were located into the pectineal capillary of Guinea fowl (Numida meleagris) as its constituent blood cells and sufficiently given the indication that it were actively involved into the process of phagocytosis. It also means the pecten oculi has engaged into the function of immunity development by way of opting the phagocytic nature by heterophils.

The luminal region of pectineal capillary was showing the primary and secondary lamellae and also the secondary lamellae were on the verge to expand as to tertiary while occupying the vacant luminal space. Pigment depositing globules were not only discovered in primary lamellae but it was also found in secondary lamellae with centrally placed nuclei. These exhibits were in almost concurrence with Kiama et al. (2006) in the pectineal capillaries in ostrich and Dayan and Ozaydin (2013) who has observed pectineal capillaries in different avian species. Though the different calibre of blood capillaries were seen at pecten oculi but entirely it encountered in a single cell as its outer thickness which only permit to term it as the capillary, and it were observed in the form of festoon in overall pecten oculi.

In present morphological study of the pecten oculi macroscopically its shape was not different than the shape of sail board which was started from base and travel to apex. Microscopically the study has also revealed that its base initiated from cauda of optic nerve and travels via fundus distally into the vitreous humour and ended into irregularly triangular structure called apex. The sail board shaped pecten oculi has encompassed with several pectineal folds which were vertically started from base with the connection to optic nerve and travelled in lateral undulated fashion as to snake while extending upto the apex known as bridge. When we have gone through the microscopic make-up of pecten oculi and it has shown very close resemblance with an architectural sculpture of diving spring board, an extreme model of speciality which used as sport device for water diving (Fig. 20) 
Engineering diagram of diving springboard with their different components was revealed by Barris (2013), Miller (2008) and Sprinings (1990) who had worked on functional principles of spring board and cited that a springboard work like a linear spring and any application of load over its tip move down in proportion to the load. Greater of the load to the linear spring resulted into a greater degree of deflection, and, principally it acts as per the Hooke's law of physics i.e. strain of any elastic material found directly proportional to the stress (Miller, 2008). A moveable fulcrum, the device which located at the thickest region of the springboard from where the board tapered back to the hinged anchor and forward to the tip (Jones and Miller, 1996; Miller et al. 1998). Fulcrum has to place on that position between the base and tip of diving spring board as to facilitate oscillations in a regular fashion and progressively it became smaller (Miller, 2008). Accordingly the structure, activity and place of location of fulcrum getting collaborative with the midline of initial point of middle one third segment of pecten oculi.

Microscopic structure of pecten oculi has shown the accordion folds as a festoon of blood capillaries with their elastic, collagen and reticular fibres certainly might have been working as the elastic and flexible material which work as the transmitter of mechanical energy and has identical as the linear spring of diving spring board. The largest calibred blood vessels were observed at the central linear component of microscopical structure of pecten oculi that has also might be the encouraging towards close comparison with the functional principle of diving spring board. Tip of the diving spring board has an area of perforations while making the region more submissive than rest of the board. And, the apex, which was identified as the bridge in present study as the cantilever unit at distal end of ribbon of blood capillaries might be attributed to the similarity in functioning of tip of diving spring board as the most compliant morphological component of pecten oculi. Structurally the diving spring board has similarity not only with the microscopical structure of pecten oculi but its working principle also might have been tuned with Hooke's law because of its histomorphological comparable composition. Therefore, movement of the eye as to find the prey must be credited to the sail board shaped pecten oculi for its working ability and the diving spring board with its cantilever, the apex known as the bridge contribute at large for support to the directional movement of the eye and also to provide the energy for its unremitting function by involving into self-oscillatory movement in vitreous humour and thereby the resulted process of diffusion. Moreover, the tip as the major inhabitant of melanin was not only preventing the apparatus of vision from ultraviolet light but it was also helping to protect against the light toxicity (Peters et al. 2006). Course of lateral undulated movement of snakes in water support their decent speed by propelling the water waves and retain the energy. Such movement was also recorded while having the connection of pectineal folds from base to apex. The laterally undulation pattern of accordion folds of pecten oculi also might be the tool to retain an energy after propelling the vitreous humour.

Histochemically the structural component of pectineal capillaries has demonstrated a very weak activity of alkaline phosphatase in the form of extremely faded blackish color at the basal lamina and also at the endothelium. The festoon of blood capillaries of pecten has confirmed the extreme weak activity at the endothelium and basal lamina region. In respect to the comparison of acid and alkaline phosphatase activity, the acidic was experienced very much weak rather than the alkaline phosphatase. The alkaline phosphatase activity was observed by Tsugio (1982) in the pecten of dark adapted eye in chick and demonstrated no activity. He mentioned that darkness may make the exchange of metabolites between pecten and less active vitreous humour with the similar observations by Bawa and Roy (1972) in chicken. However in the present study also it was similar with them, but when the day active i.e. diurnal birds were chosen for detecting the strength of alkaline phosphatase activity in their pecten oculi and when it revealed a very weak activity then it was required to be noted that alkaline and acid phosphatase were those enzymes which hydrolyzes the phosphate group and act as catalyst to speed up the chemical reaction in cell at basic and acidic environment with optimum $\mathrm{pH}$ of 10.5 and 5.3 respectively. In present studies against both the acid and alkaline phosphatase the activities were recorded as very weak with the close resemblance to negative, which made it known that if the activity found in elevation then the organ component indicating its association with certain medical condition (Wikipedia, 2017). And, in the present study of pecten oculi in Guinea fowl where activity was near to negative for both acidic and alkaline phosphatase indicating that the components of pecten were extreme, active and vigorously performing in vitreous humour.

The strong activity of glycogen was noticed at optic nerve and the collagen fibres which provide potential structure of pectineal capillaries. As per the property of glycogen it has displayed the strong red-purple color of activity at both endothelial and basal lamina region of capillary. Even it has show off the strongest presence of activity at surrounding connective tissue septa of an apex, the bridge of pecten. Venkatesan and Ramesh (2006) has studied pecten oculi in domestic fowl and confirmed the PAS positive reaction in a whole pecten and as the secretory product they observed the glycogen in the form of mucopolysaccharide in pecten oculi. In the present study of 
pecten oculi most of the components of it and its surroundings comprising optic nerve, collagen fibers of potential pectineal capillaries, endothelial and basal lamina region of capillaries and even the surrounding connective tissue septa of an apex, the bridge were showing PAS positive activity in greater or lesser extent and conclusively the components were remained as the source of energy for incessant working for pecten oculi.

The purposeful presence of melanin in pecten oculi, particularly at the pectineal capillaries and also around the surrounding of irregularly triangular apex, bridge was shown in intense higher concentration. Similarities of higher degree of reaction also were located at pigmented epithelium of retina and also at the laterally placed blood capillaries of undulated fold components of pecten. These observations were in exact similarity by other investigators who has explored in different avian species as Onuk et al. (2013) in stork (Ciconia ciconia), Dayan and Ozaydin (2013) in different avian species, Braekevelt (1993) in great horned owl, Orhan et al. (2011) in quail (Coturnix coturnix japonica) and Rajab (2012) in sparrow hawk (Accipiter nisus). The presence of melanin involves into the function to provide structural support and protection to pecten oculi from ultraviolet light and oxygen radicals.

In accordance to the documentation which was made available by several workers against various functions of pecten oculi in different species of birds as to protect the eye from harmful effect of ultraviolet radiation created by sunlight as per Onuk et al. (2013) intraocular pressure and pH regulation, stabilization of the vitreous, reduction of intraocular glare, serving as a blood and fluid barrier for the retina and vitreous body, supplementation of nutrition, oxygen gradient supply to the retina, keeping constant intraocular temperature as mentioned by Jezler et al. (2010) flow of oxygen and carbon dioxide between the capillaries and vitreous body, detoxification of the retina as per Micali et al. (2012), nourishment of the avascular retina and vitreous body, protecting the visual efficiency of the eye as mentioned by Rajab (2012), ocular sextant Pourlis (2013) were fitting with the findings revealed during present study. But along with the mentioned a pecten oculi of Guinea fowl (Numida meleagris) has also haemostatic organ, work as support system to retina for its normal functioning of image capture to get the visual acuity, fight off diseases and infection, engage into the function of immunity, absorbing unit of heat and maintaining energy while performing for the bird of higher metabolic rate and also work as the elastic and flexible material which carry out as the transmitter of mechanical energy while working as the source of it for vitreous by way of diffusion.

\section{Conclusion:-}

On the basis of studies what has been done on 18 eyes of Pecten oculi in Guinea fowl birds. It is concluded that the pecten oculi was discovered in a structure of festoon of blood capillaries with elastic, collagen and reticular fibers. It was corresponding with the structure of the water diving sport machine popularly known as the spring diving board. Its functioning principle was also being matched with Hook's law as how the diving spring board works. Morphologically its shape was also supportive towards its structure which found as the sail board. The guinea fowl when attempts to find a prey as diurnal bird the moves their eyes which could be possible due to its sail board shaped pecten oculi. It works as the diving spring board with the apex known as bridge. Bridge functions as the cantilever which contribute at large for support to the directional movement of the eye and also to provide the energy for its unremitting function by involving into self-oscillatory movement in vitreous humour and thereby the methodology of diffusion. Moreover, the tip as the major inhabitant of melanin was not only preventing the apparatus of vision from ultraviolet light but it was also helping to protect against the light toxicity. Pecten as the organ functions to provide protection to the eyes from harmful effect of ultraviolet radiation created by sunlight, maintains intraocular pressure and $\mathrm{pH}$, stabilizes the vitreous, reduces the intraocular glare, serves as the blood and fluid barrier for the retina and vitreous body, supplement nutrition and oxygen gradient to the retina, maintains constant intraocular temperature, flow of oxygen and carbon dioxide between the capillaries and vitreous body, detoxification of the retina, nourishes avascular retina and vitreous body, protects the visual efficiency of the eye and also the ocular sextant. Other than the mentioned, pecten oculi of Guinea fowl (Numida meleagris) has also performs as the haemostatic organ, support system to retina for its normal functioning of image capture while getting the visual acuity, fight off diseases and infection, engage into the function of immunity, absorbing unit of heat and maintaining energy in the bird which work with higher metabolic rate and also it works as the elastic and flexible material which carry out as the transmitter of mechanical energy while working as the source of it for vitreous by way of diffusion. 


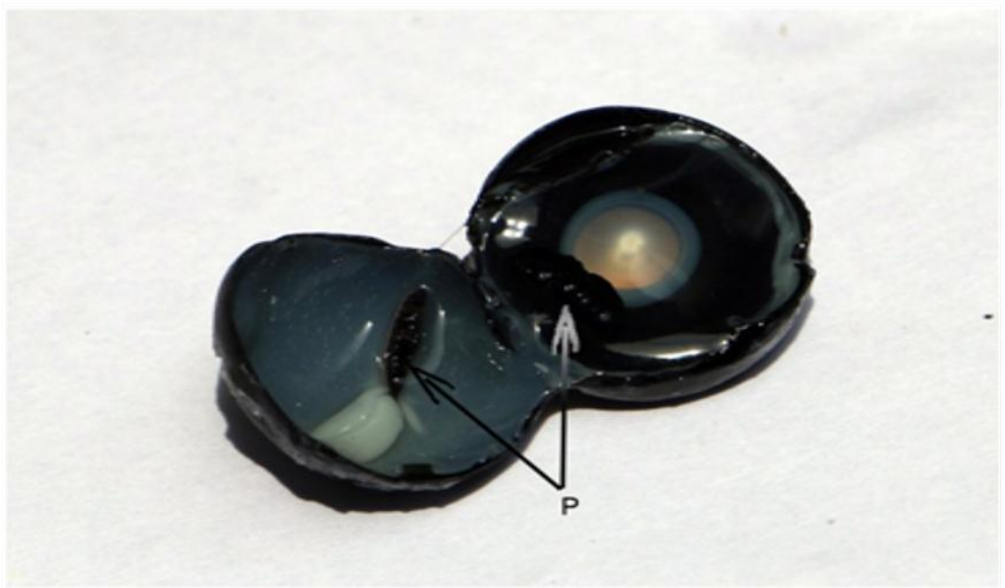

Fig 1:-Showing the pecten component $(\mathrm{P})$ in either half of eyeball after equatorial dissection.

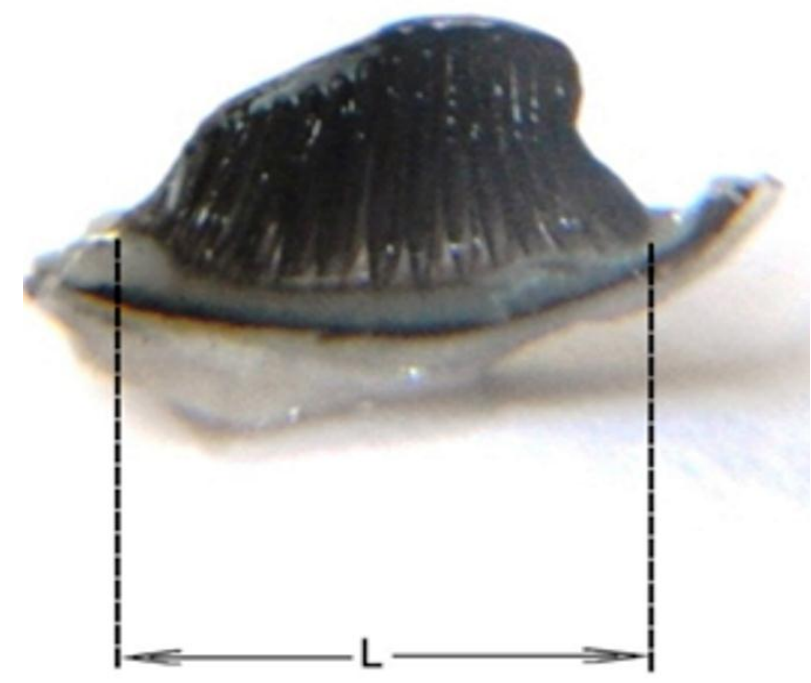

Fig 2:-Showing the length of base (L) of the pecten oculi.

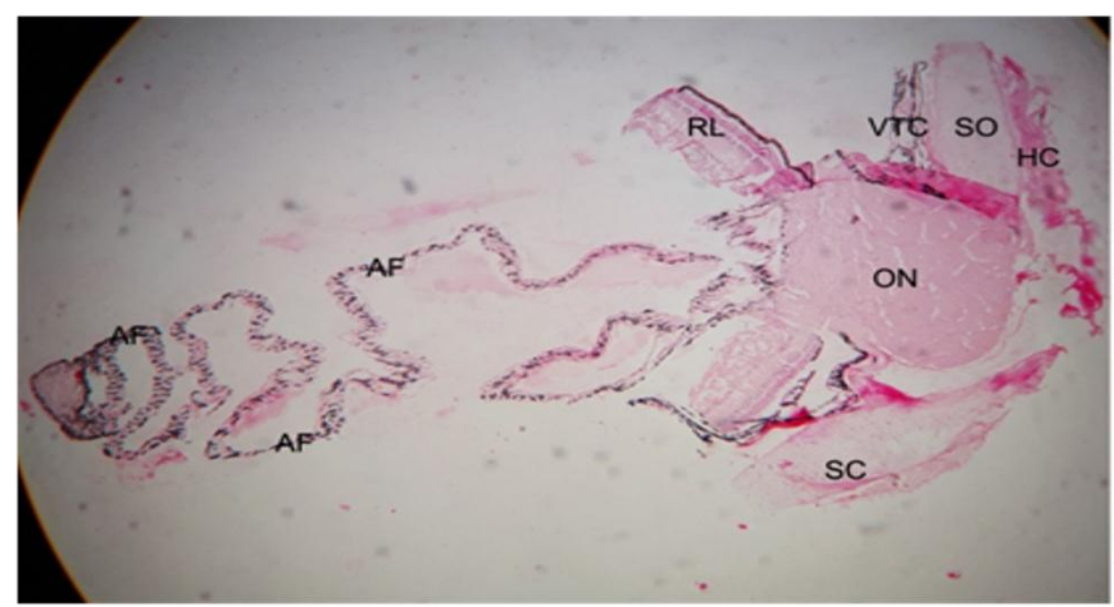

Fig 3:-photomicrograph showing the pecten oculi with its surrounding structures including scleral tunic(SC), scleral ossicles (SO), hyaline cartilage (HC), vascular tunic choroid (VTC), optic nerve (ON) and retinal layers (RL). Haematoxylin and Eosin 5X. 


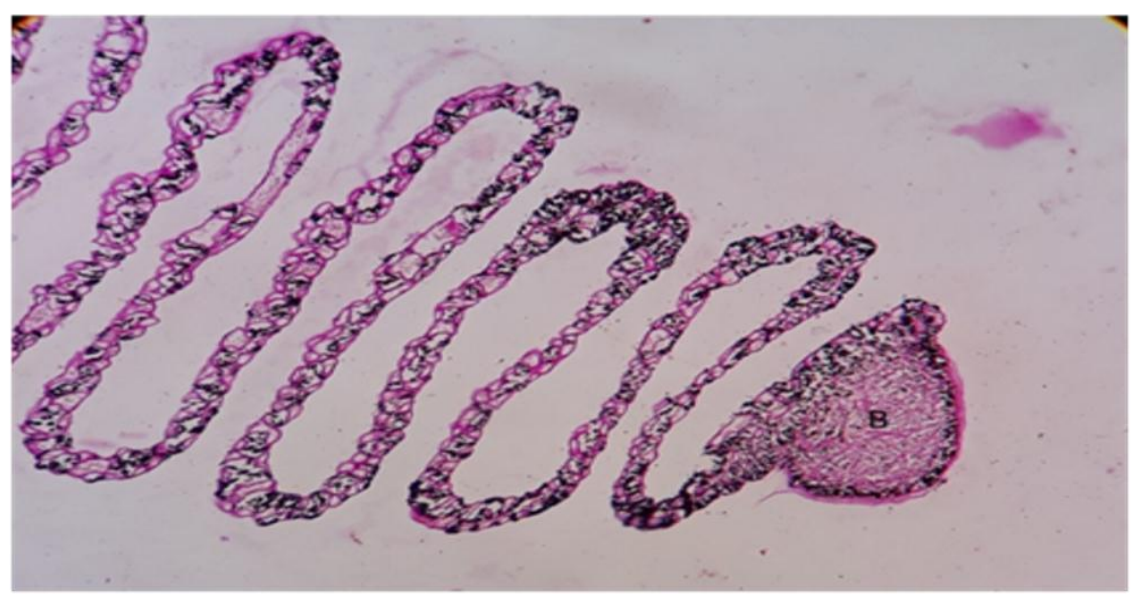

Fig 4:-Photomicrograph showing the cantilever fashioned irregularly trianglular shaped bridge (B).PAS 10X.

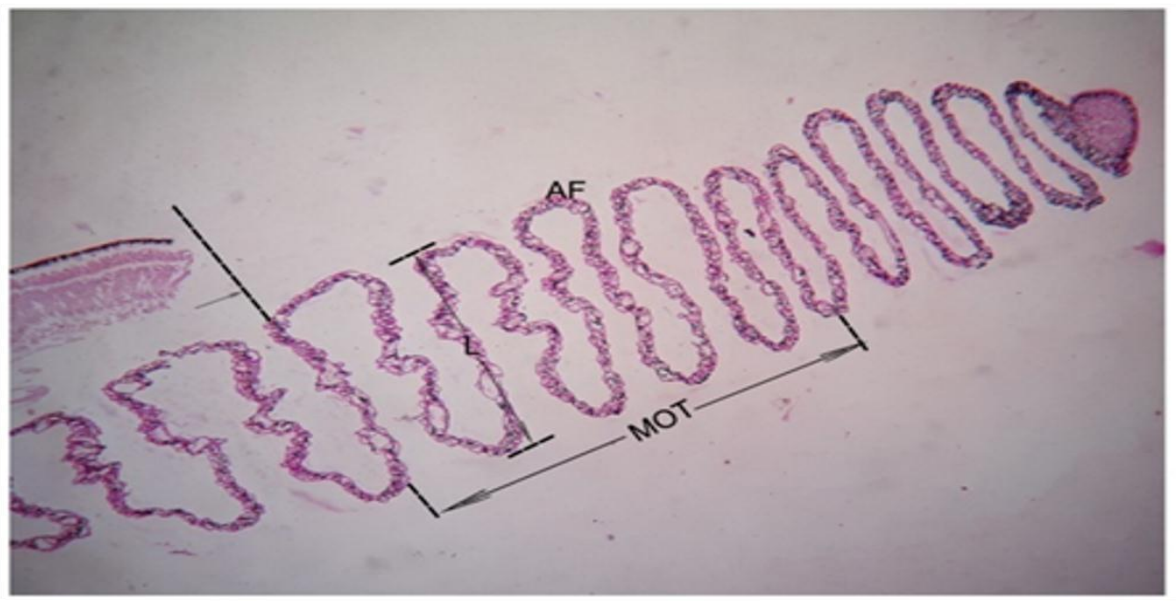

Fig 5:-Photomicrograph showing the middle one third (MOT) segment of pecten with maximum length (L) of accordion folds (AF). Arrow is showing initial point of MOT. PAS 10X.

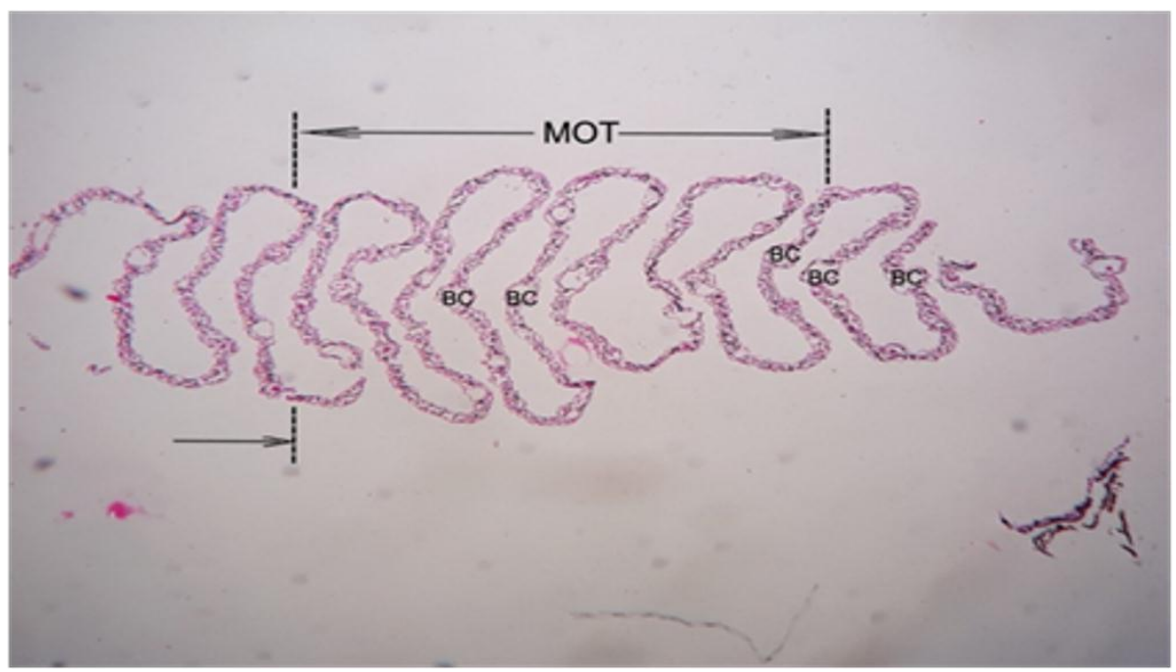

Fig 6:-Photomicrograph showing middle one third (MOT) of pecten with number of blood capillaries (BC) in variable diameters. Arrow is showing the initial point of MOT.Haematoxylin and Eosin 10X. 


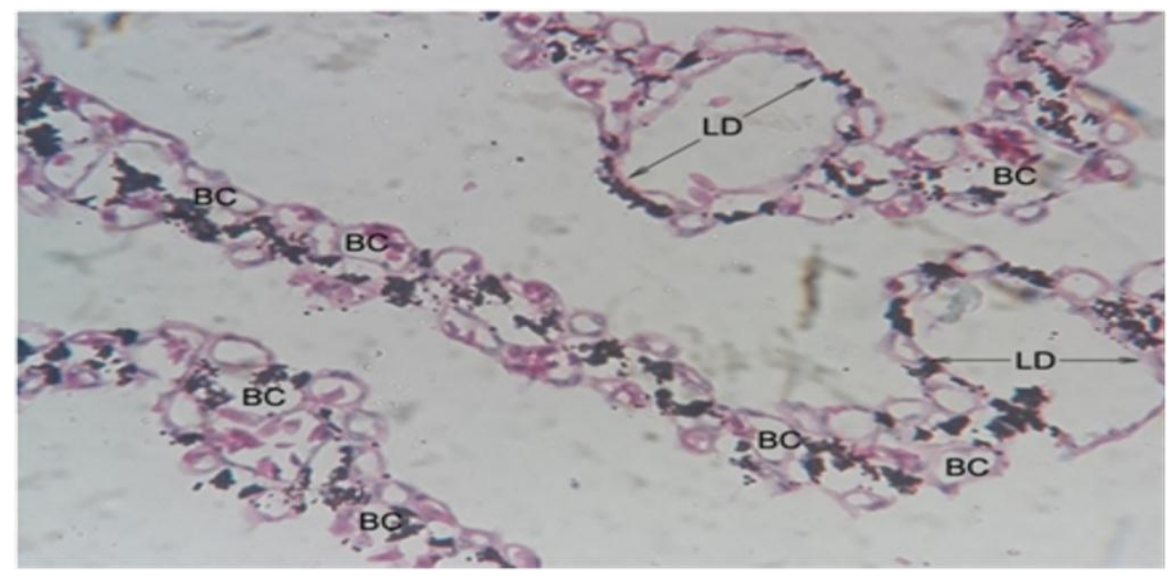

Fig 7:-Photomicrograph showing the pectineal blood capillaries $(\mathrm{BC})$ with maximum luminal diameter (LD).Haematoxylin and Eosin 40X.

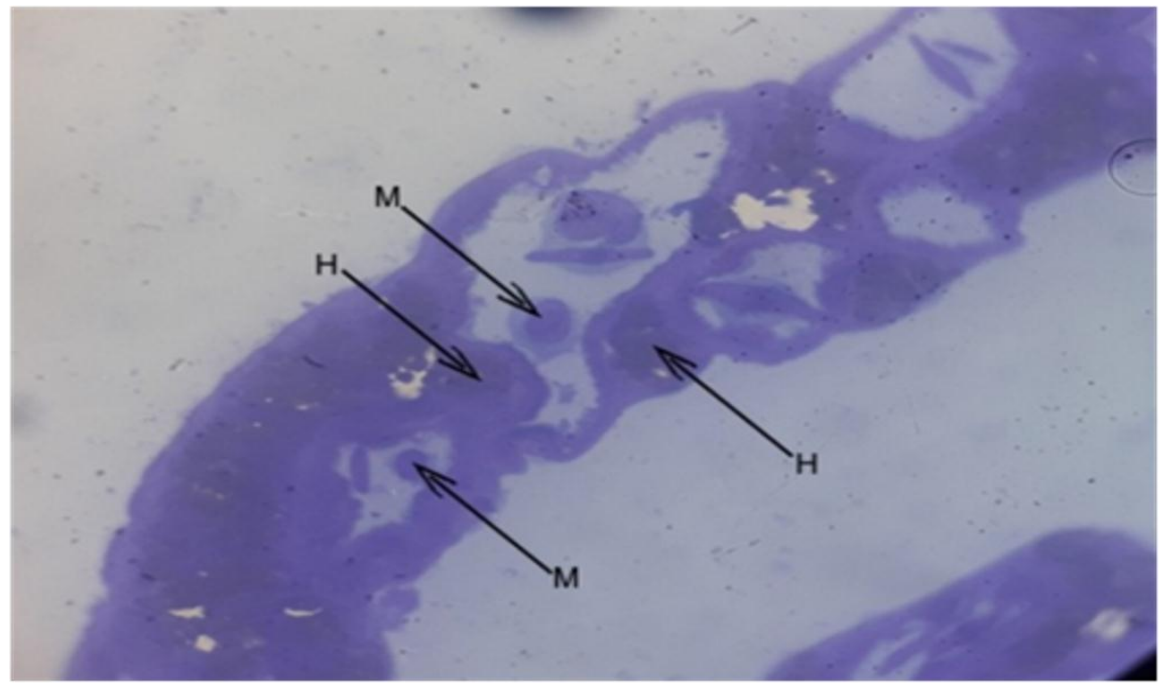

Fig 8:-Photomicrograph showing the pectineal blood capillaries with heterophils $(\mathrm{H})$ and monocyte $(\mathrm{M})$. Toulidine Blue 100X.

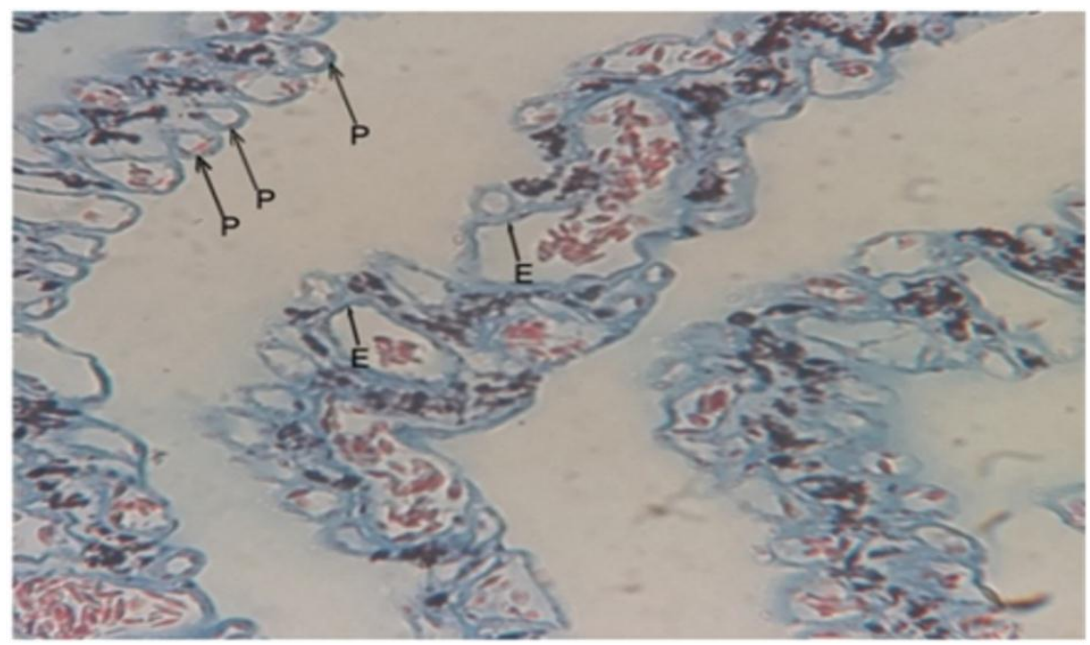

Fig 9:-Photomicrograph showing capillary with endothelial cells (E) and pericytes (P).Azan Trichome 40X. 


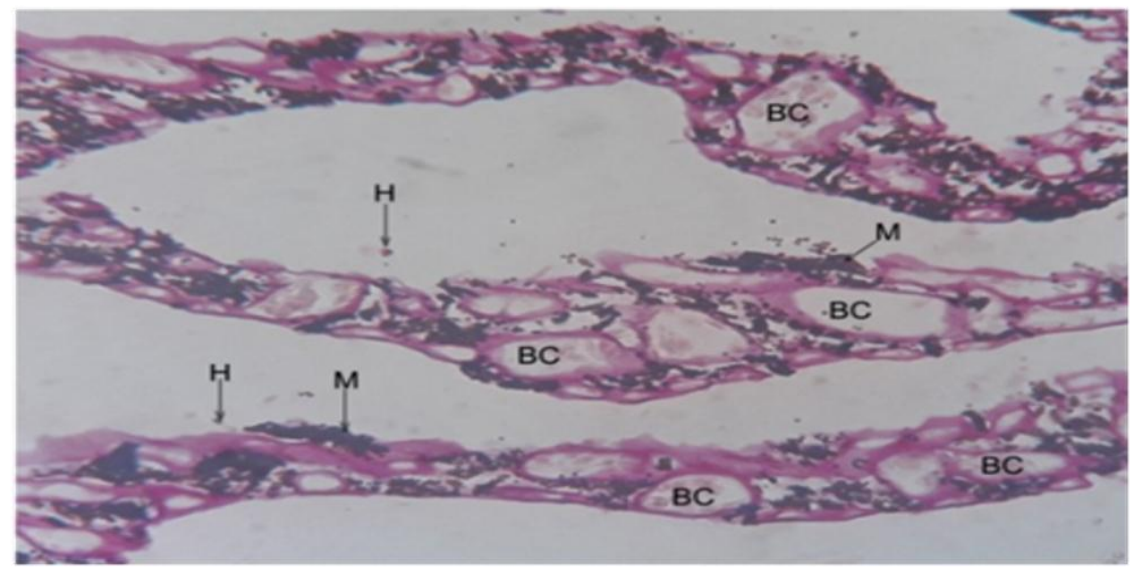

Fig 10:-Photomicrograph showing pectineal blood capillaries $(B C)$ with hyalocyte $(\mathrm{H})$ and melanocyte $(\mathrm{M})$ PAS 40X.

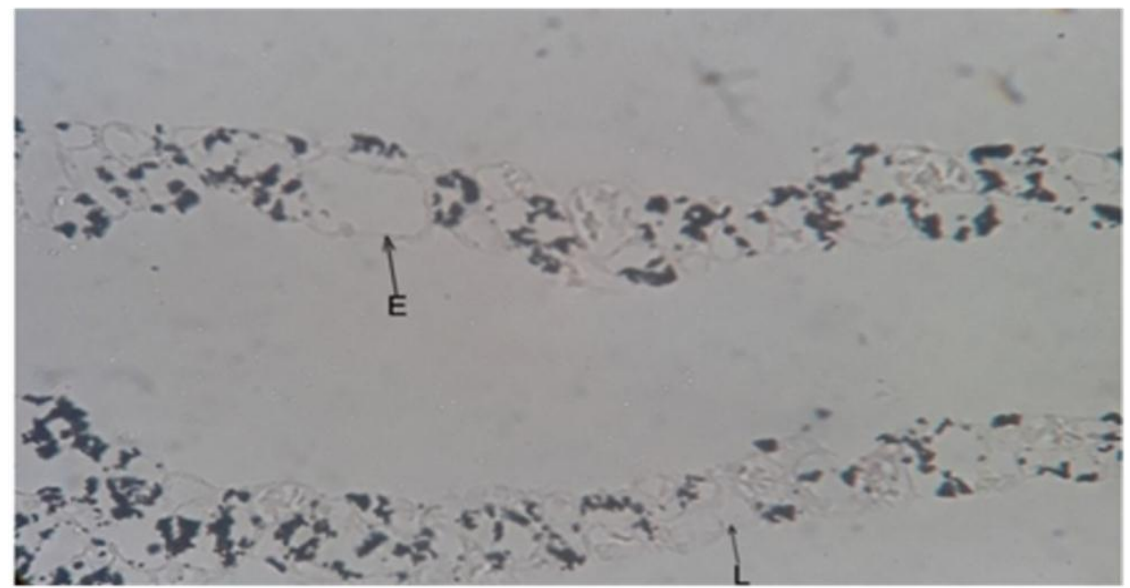

Fig 11:-Photomicrograph showing basal lamina (L) and endothelium (E) with very weak strength of alkaline phosphatase activity. Alkaline Phosphatase 40X.

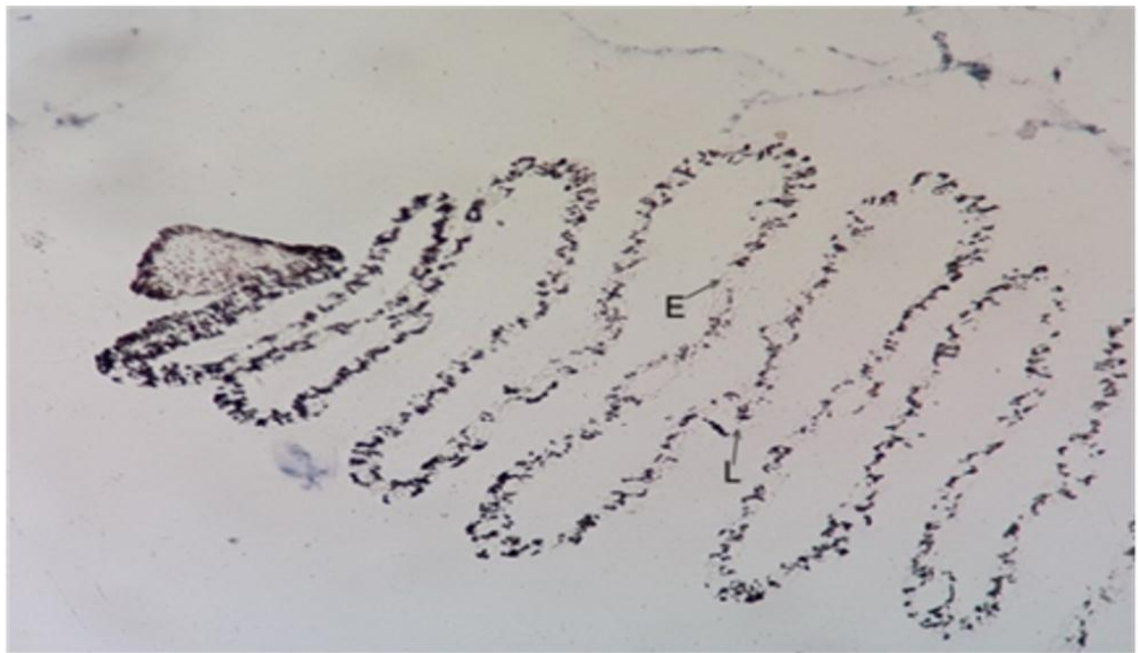

Fig 12:-Photomicrograph showing very weak activity of acid phosphatase in capillary of pecten at basal lamina (L) and endothelium (E).Acid Phosphatase 10X. 


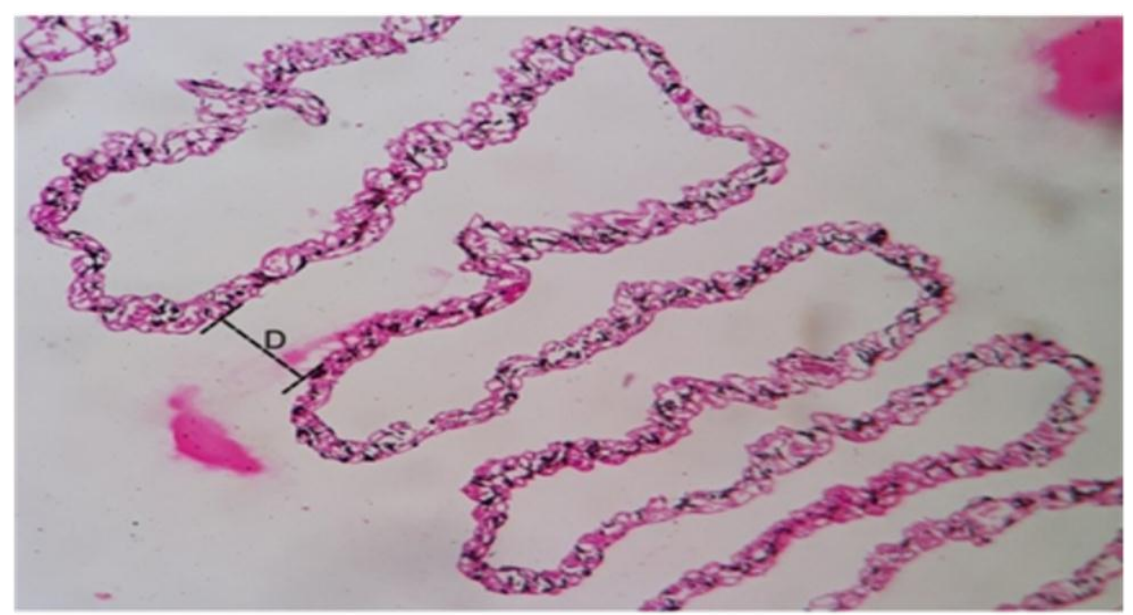

Fig 13:-Photomicrograph showing the middle one third segment of pecten with maximum distance (D) between two pectineal folds.PAS 10X.

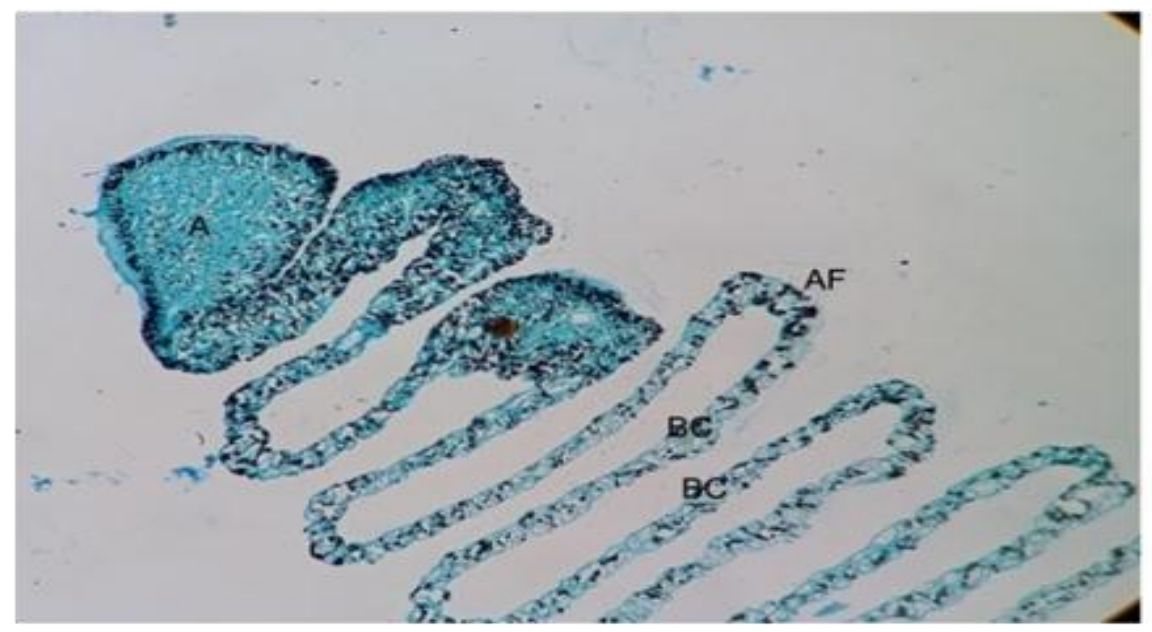

Fig 14:-Photomicrograph showing the apex (A) with higher concentration as in black colour at accordion fold (AF) and blood capillaries (BC).Fontana Massons Silver 10X.

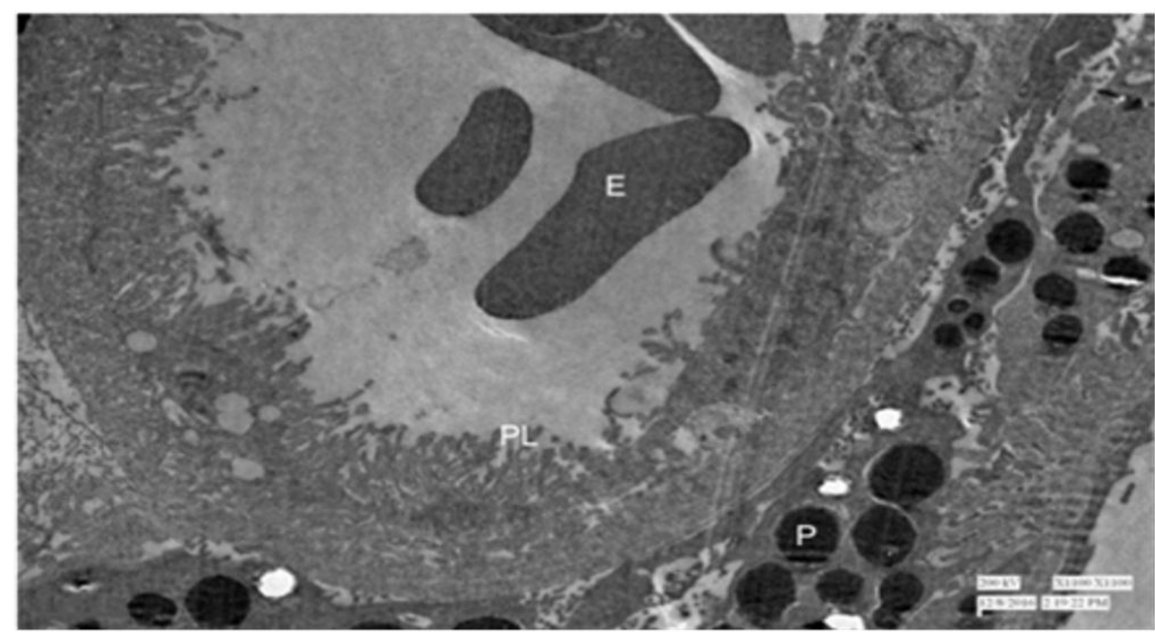

Fig 15:-Showing nucleated erythrocyte (E) surrounded by primary lamellae (PL) and extra vascular pigment (p) at outside the capillary.1100X. 


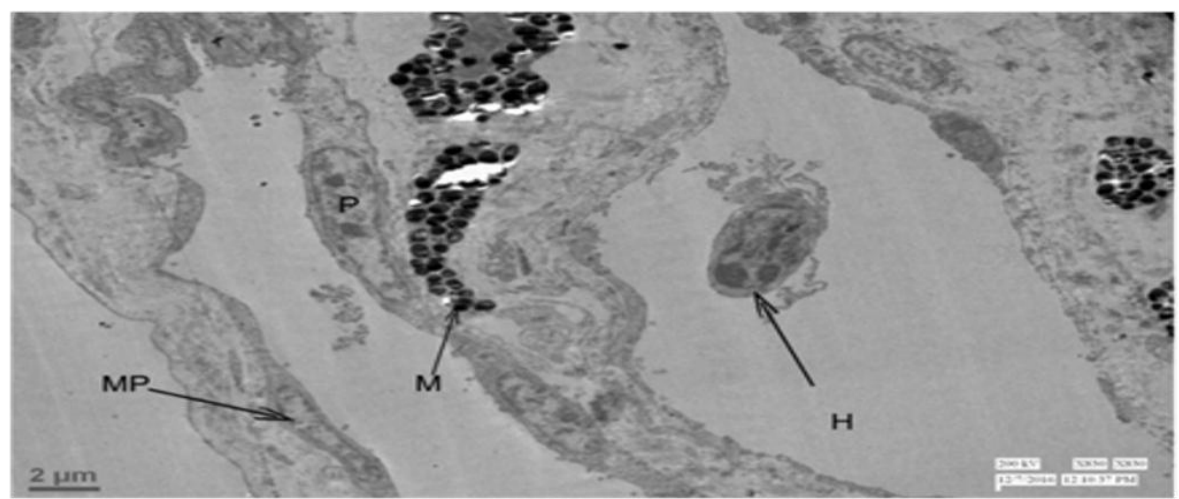

Fig 16:-Transmission electron micrograph showing the pectineal capillary with melanocyte (M), melanocyte process (MP), heterophil (H) and pericyte (P).830X.

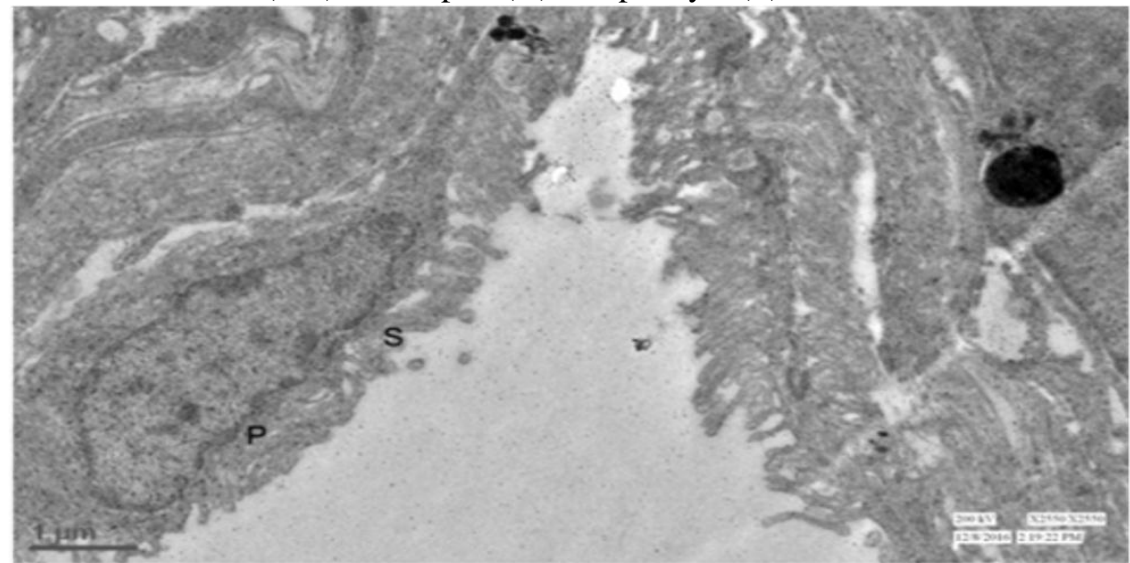

Fig 17:-Transmission electron microscopy showing the primary $(\mathrm{P})$ and secondry $(\mathrm{S})$ lamellae at luminal surface of the pectineal capillary.2550X.

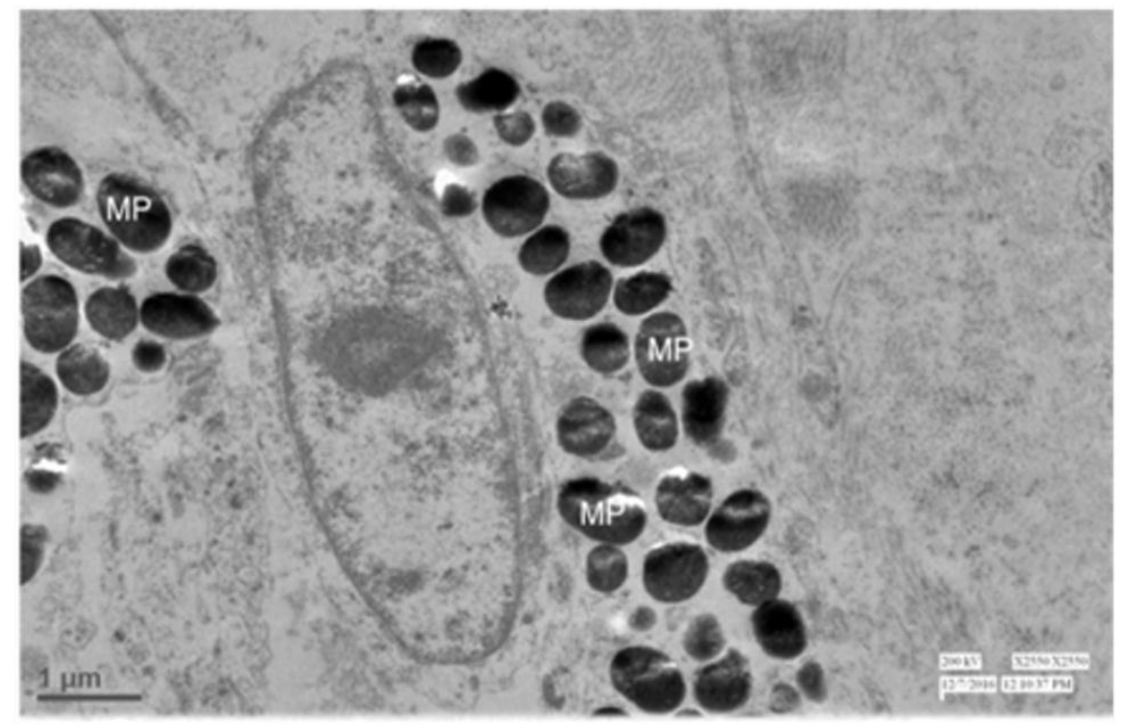

Fig 18:-Transmission electron micrograph showing the melanin pigment (MP) depositing globules at secondry lamellae of luminal component of pectineal capillary. 2550X. 


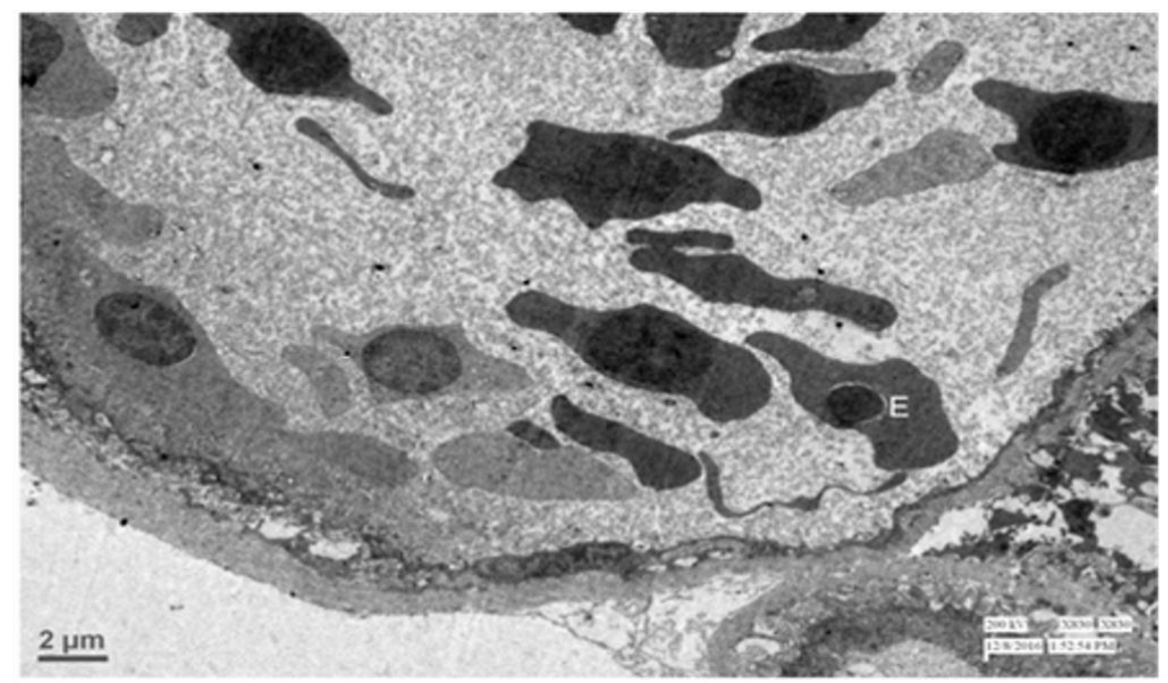

Fig 19:-Transmission electron micrograph showing the lumen of pectineal capillary with nucleated erythrocyte (E).830X.

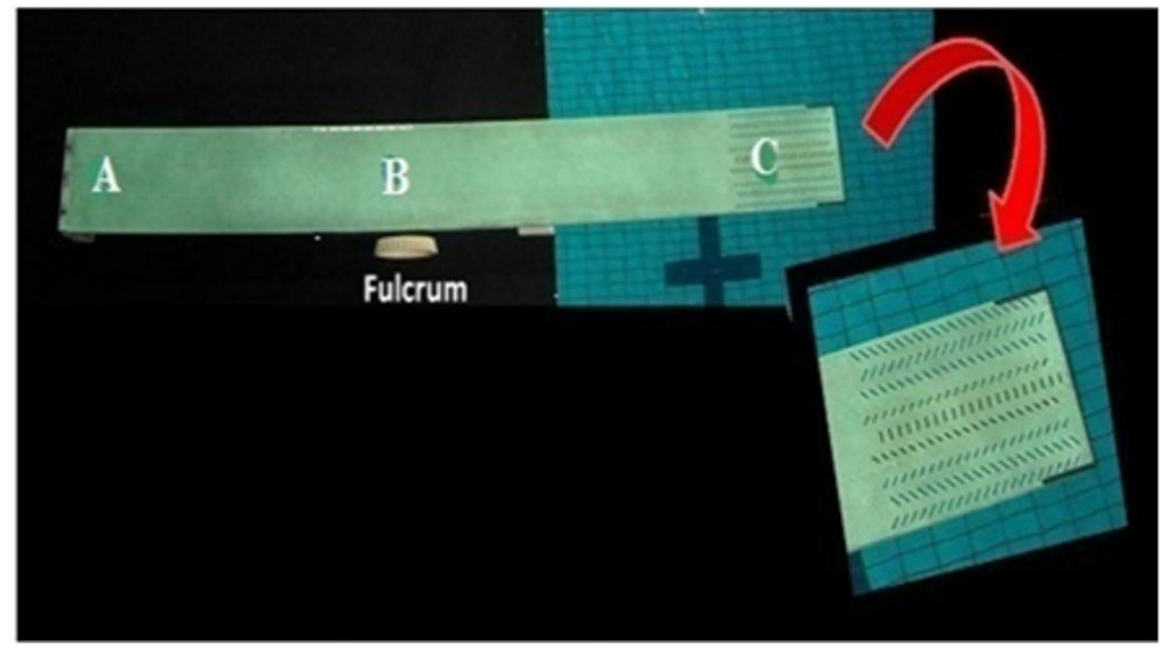

Fig 19:-Transmission electron micrograph showing the lumen of pectineal capillary with nucleated erythrocyte (E). $830 \mathrm{X}$

Table 1:-Different micrometrical observations with respect to pecten oculi

\begin{tabular}{|c|c|c|c|c|c|c|}
\hline $\begin{array}{c}\text { Sample } \\
\text { No. }\end{array}$ & $\begin{array}{c}\text { Maximum } \\
\text { Height of } \\
\text { pecten oculi } \\
\text { at base in } \\
\text { mm }\end{array}$ & $\begin{array}{c}\text { Maximum } \\
\text { Length of } \\
\text { pecten oculi } \\
\text { in } \mathbf{~ m m}\end{array}$ & $\begin{array}{c}\text { Total length } \\
\text { of pecten } \\
\text { oculi from } \\
\text { optic nerve to } \\
\text { apex in } \boldsymbol{\mu m}\end{array}$ & $\begin{array}{c}\text { Maximum } \\
\text { length of } \\
\text { accordion } \\
\text { folds } \\
\text { in } \boldsymbol{\mu m}\end{array}$ & $\begin{array}{c}\text { Maximum } \\
\text { Distance } \\
\text { between two } \\
\text { accordion folds } \\
\text { in } \boldsymbol{\mu m}\end{array}$ & $\begin{array}{c}\text { Maximum } \\
\text { luminal } \\
\text { diameter of } \\
\text { capillaries } \\
\text { in } \boldsymbol{\mu m}\end{array}$ \\
\hline P1 & 3.549 & 5.731 & 298 & 82 & 11 & 8 \\
\hline P2 & 3.235 & 6.339 & 340 & 72 & 13 & 9 \\
\hline P3 & 3.485 & 5.987 & 300 & 76 & 10 & 7 \\
\hline P4 & 3.335 & 5.689 & 462 & 88 & 13 & 14 \\
\hline P5 & 2.988 & 5.248 & 346 & 46 & 11 & 6 \\
\hline P6 & 3.219 & 6.235 & 440 & 94 & 10 & 12 \\
\hline P7 & 3.458 & 5.836 & 320 & 56 & 11 & 7 \\
\hline P8 & 3.568 & 5.831 & 400 & 48 & 9 & 7 \\
\hline P9 & 3.138 & 6.289 & 328 & 60 & 10 & 8 \\
\hline
\end{tabular}




\begin{tabular}{|c|c|c|c|c|c|c|}
\hline $\mathrm{P} 10$ & 3.453 & 5.798 & 414 & 55 & 12 & 7 \\
\hline $\mathrm{P} 11$ & 3.325 & 6.325 & 420 & 52 & 11 & 6 \\
\hline P12 & 3.548 & 5.879 & 348 & 59 & 9 & 6 \\
\hline P13 & 3.435 & 5.746 & 298 & 60 & 13 & 12 \\
\hline P14 & 2.899 & 5.428 & 425 & 49 & 12 & 4 \\
\hline P15 & 3.126 & 5.825 & 420 & 57 & 10 & 5 \\
\hline P16 & 3.854 & 6.236 & 457 & 64 & 12 & 8 \\
\hline P17 & 3.865 & 5.758 & 387 & 58 & 13 & 8 \\
\hline P18 & 3.318 & 6.248 & 428 & 50 & 11 & 7 \\
\hline Average & 3.378 & 5.913 & 379.500 & 62.556 & 11.167 & 7.833 \\
\hline SD & 0.259 & 0.313 & 57.042 & 14.147 & 1.339 & 2.550 \\
\hline SE & 0.061 & 0.074 & 13.445 & $\mathbf{3 . 3 3 5}$ & 0.316 & 0.601 \\
\hline
\end{tabular}

P: Pecten, SD:Standard Deviation, SE: Standard Error

\section{References:-}

1. Anonyms: Handbook in electron microscopy. Sophisticated analytical instrumentation facility, electron microscope facility, department of Anat. New Delhi; 2015.

2. Bancroft, J. D. and Cook, H. C.: Manual of histological techniques and their diagnostic applications, Churchil livingstone Publication; 1994.

3. Barris: Ph.D. Thesis entitled 'An examination of learning design in elite springboard diving. Quinsland university of technology, Brisbane, Australia 2013;2-178.

4. Bawa, S. R. and Roy, Y. C.: Effect of dark and light adaptation on the retina and pecten of chicken. Experimental Eye Res. 1972;13:92-97.

5. Bawa, S. R. and Roy, Y. C.: Structure and function of vulture pecten. Punjab University,Chandigarh, Ind. Acta. Anat. 1974;89: 473-480.

6. Bito, L. Z., DiBenedetto, F. E. and Stetz, D.: Homeostasis of the retinal micro-environment: I. magnesium, potassium and calcium distributions in the avian eye. Experimental Eye Res. 1982;34(2):229-237.

7. Bonney, R., Rohrbaugh, J. R. and Ronald: Handbook of Bird Biology ( $2^{\text {nd }}$ ed.), Princeton, NJ: Princeton University Press; 2004.

8. Brach, V.: The effect of intraocular ablation of the pecten oculi of the chicken. Invest. Ophthalmol. 1975;14 (2):166-168.

9. Brach, V.: The functional significance of the avian pecten: A review. The condor 1977;79: 321-327.

10. Braekevelt, C. R.: Electron microscopic observations on the pecten of the nighthawk (Chordeiles minor). Ophthalmol. 1984;189(4):211-220.

11. Brakevelt, C. R.: The fine structure of the pecten of the pigeon (Columbia livia). Opthalmol. 1988;196 (3):151159.

12. Braekevelt, C. R.: Fine structure of the pecten oculi of the red tailed hawk (Buteo jamaicensis). Anat. Histol. Embryol. 1991;20 (4):354-362.

13. Braekvelt, C. R.: Electron microscopic observation on the pecten of the great blue heron (Ardea herodias). Histol. Histopathol. 1991;6(3):345-351.

14. Braekevelt, C. R.: Fine structure of the pecten oculi in the great horned owl (Bubo virginianus). Histol. and histopathol. 1993;8:9-15.

15. Braekevelt, C. R.: Fine structure of the pecten oculi in the American crow (Corvus brachyrhynchos). Anat. Histol. Embryol. 1994;23 (4):357-366.

16. Braekevelt, C. R.: Fine structure of the pecten oculi of the emu (Dromaius novaehollandiae). Tissue cell. 1998;30 (2):157-165.

17. Braekevelt, C. R. and Richardson K. C.: Fine structure of the pecten oculi in the Australian galah (Eolophusroseicapillus) (Aves). Histol. Histopathol. 1996;11(3):565-571.

18. Corona, M., Scala, G. and Perrella, A : Angioarchitecture of the duck pecten. Italian National Res. Council; 2004.

19. Cunha-vaz, J. G.: The blood-retinal barriers. Documenta opthalmol. 1976;41(2):287-327.

20. Dayan, M. O. and Ozaydin, T.: A comparative morphometrical study of the pecten oculi in different avian species. The Scientific World Journal. 2013;doi: 10.1155/2013/968652. 
21. Dieterich, C. E., Dieterich, H. J., Spycher, M. A. and Pfautsch M.: Fine structural observations of the pecten oculi capillaries of the chicken. Cell and tissue Res. 1973;146(4): 473-489.

22. Eichorn, M. and Flugel, C.: Histochemical demonstration of carbonic anhydrase and $\mathrm{Na}^{+} / \mathrm{K}^{+}$-ATPase in the pecten oculi of the fowl. Exp. Eye Res. 1988;47(1): 147-153.

23. Ferreira, T.A., Turner, G. A. and Ferreira, M. F. : Haemodynamics of the pectinis oculi artery in American pekin ducks (Anas platyrhynchos domestica). Vet opthalmol. 2015;19(5):409-13.

24. Gerhardt, H., Liebner, S. and Wolburg, H.: Pecten oculi of the chicken as a new in vivo model of the blood brain barrier. Cell Tissue Res. 1996;285(1):91-100.

25. Gultiken, M. E., Yildiz, D., Onuk, B. and Karayigit M. O.: The morphology of the pecten oculi in the common buzzard (Buteo buteo). Vet Ophthalmol. 2012;15(2): 72-76.

26. Haller, N. K., Lind, O., Steinlechner, S. \& Kelber, A.: Thesis-The influence of motion on spatial contrast sensitivity in budgerigars (Melopsittacus undulatus). University of Veterinary Medicine Hannover. 2014.

27. Jezler, P. C. O. C., Braga, M. B. P., Perlmann, E., Squarzoni, R., Borella, M. I., Barros, P. S. M., Milanelo, L. and Antunes A.: Histological analysis of eyeballs of the striped owl (Rhinoptynxclamator).Microscopy: Sci. Tech., Applications and Education A. Mendez-Vilas and J. Diaz (Eds.); 2010.

28. Jones, I. and Miller, D.: Influence of fulcrum position on springboard responce and take-off performance in the running approach. Journal of Applied Biomechanics. 1996;12(3): 383-408.

29. Kevin, O. D.: The fundus and fovea centralis of the albatross (diomedea cauta cauta gould). The british journal of ophthalmol. 1940;24:201-207.

30. Kiama, S. G., Bhattacharjee, J., Maina, J. N. and Weyrauch, K. D.: A scanning electron microscope study of the pecten oculi of the black kite (Milvus migrans): possible involvement of melanosomes in protecting the pecten against damage by ultraviolet light. Journal Anat. 1994;185 (3):637- 42.

31. Kiama, S. G., Bhattacharjee, J., Maina, J. N. and Weyrauch, K. D.: Surface specialization of the capillary endothelium in the pecten oculi of the chicken, and their overt roles in pectineal haemodynamics and nutrient transfer to the inner neural retina. Acta. Biol. Hung. 1997;48 (4):473-83.

32. Kiama, S. G., Maina, J. N., Bhattacharjee, J. and Weyrauch, K. D.: Functional morphology of the pecten oculi in the nocturnal spotted eagle owl (Bubo bubo africanus), and the diurnal black kite (Milvus migrans) and domestic fowl (Gallus gallus var. domesticus): a comparative study. Journal Zool. Lond. 2001;254: 521-528.

33. Kiama, S. G., Maina, J. N., Bhattacharjee, J., Mwangia, D. K., Machariae, R. G. and Weyrauch, K. D. : The morphology of the pecten oculi of the ostrich (Struthio camelus). 2006;188(6): 519-528.

34. Kiama, S. G., Maina, J. N., Bhattacharjee, J., Weyrauch, K. D. and Gehr, P.: A scanning electron microscope study of the luminal surface specializations in the blood vessels of the pecten oculi in a diurnal bird, the black kite (Milvus migrans). Ann Anat. 1998;180(5): 455-460.

35. Liebner, S., Gerhardt, H. and Wolburg, H. : Maturation of the blood-retina barrier in the developing pecten oculi of the chicken. Developmental Brain Res. 1997;100: 205-219.

36. Llombart, C., Nacher, V., Ramos, D., Luppo, M., carretero, A., Navarro, M., Melgarejo, V., Armengol, C., Rodriguez, B. A., Mendes, J. L. and Ruberte, J.: Morphological characterization of pecteneal hyalocytes in the developing quail retina. Journal Anat. 2009;215(3):280-291.

37. Luna, L. G. : Manual of histologic staining methods of the armed forces institute of pathology, $3^{\text {rd }}$ edition, McGRAW-HILL Book Company, Newyork; 1968.

38. Mann I. C.: The function of the pecten. The British journal of ophthalmol, Henry George plimmer research fellow, London; 1924.

39. Mann, I. C., F. R. C. S. and D. O. M. S. (un-mentioned) : The pecten of Gallus domesticus. Henry George plimmer fellow in pathol. with 21 text-figures. : 413-442.

40. Matsunaga, N. and Tsugio, A. : Pecten of the chick eye demonstrated by vascular casts. Okajimas Folia Anat. Jpn. 1990;67(4): 263-270.

41. Meyer D. B.: The Avian Eye and its Adaptations. In: Crescitelli F. (eds) The Visual System in Vertebrates. Handbook of Sensory Physiology, vol 7 / 5. Springer, Berlin, Heidelberg; 1977.

42. Micali, A., Pisani, P., Ventrici, C., Puzzolo, D., Roszkowska, A. M., Spinella, R. and Aragona, P.,: Morphological and Morphometrical study of the Pecten Oculi in the Budgerigar (Melopsittacus undulatus). The Anat. Record. 2012;295 (3):540-550.

43. Miller, D.: Springboard and platform diving. Indian V. Zatsiorsky (Ed.), Biomechanics in Sport. 2008;326-348.

44. Miller, D., Osborne, M. and Jones, I.: Springboard oscillation during hurdle flight. Journal of Sport Sci. 1998;16: 571-583. 
45. Mohammed, A. G. and Shaimaa, A. A.: Comparative morphological and histological study of the pecten oculi in two species of Iraqi birds (Falco tinnunculus L. and Streptopelia decaocto F.). Article in Baghdad Sci. Journal. 2015;1-12.

46. Onuk, B., Tutuncu, S., Alan, A., Kabak, M. and Ince N. G.: Macroanatomic, light and scanning electron microscopic studies of the pecten oculi in the stork (Ciconia ciconia). Microscopy Res. and Tech. 2013;76:963967.

47. Orhan, O., Ekim, O. and Bayraktaroglu A. G.: Morphological investigation of the pecten oculi in quail (Coturnix coturnix japonica) Ankara Univ Vet Fak Derg. 2011;58: 5-10.

48. Peters, S., Lamah, T., Kokkinou, D., BartzSchmidt, K. U., Schraermeyer, U. Z. and Naturforsch C.: Melanin protects choroidal blood vessels against light toxicity. Z. Naturforsch. 2006;61(56): 427-433.

49. Pettigrew, J. D.: A role for the avian pecten oculi in orientation to the sun? DOI: 10.1007/978-3-662-11147-5-4. In book: Animal migration, navigation and homing. : 1978;42-54.

50. Pettigrew, J. D., Walllman, J. and Christine, F. W.: Saccadic oscillations facilitate ocular perfusion from the avian pecten. Nature. 1990;343:362-363.

51. Pollard, A. L.: Visual constraints upon avian behavior. Thesis submitted to Cardiff School of Biosciences, Cardiff University for Ph.D., U585391: 2009; 26-28.

52. Pourlis, A. F.: Scanning Electron Microscopic Studies of the Pecten Oculi in the Quail (Coturnix coturnix japonica), Hindawi Pub. Corporation, Anat. Res. Inter.: 2013;650601:6.

53. Rahman, M. L., Lee, E., Aoyama, M. and Sugita, S.: Light and electron microscopy study of the pecten oculi of the jungle crow (Corvus macrorhynchos). Okajimas Folia Anat. Jpn. 2010;87 (3):75-83.

54. Rajab, J. M.: Morphological and histological description of the pecten oculi in the sparrow hawk (Accipiter nisus). Diyala Journal of pure sci. 2012;8(1).

55. Seaman, A. R. and Storm, H.: A correlated light and electron microscope study on the pecten oculi of the domestic fowl (Gallus domesticus). Exp Eye Res. 1963;2(2):163-172.

56. Shahi, B. N., Singh, Brijesh and Varma, S. K.: Inheritance of Incubation traits of guinea fowl using transformations. Indian Journal of Animal Sci. 2003; 73 (I): 100-101.

57. Singh, U. B. and Sulochana: Handbbok of histological and histochemical techniques, Premier pub. house, Hyderabad; 1996.

58. Smith, B. J., Smith, S. A. and Braekevelt, C. R.: Fine structure of the pecten oculi of the barred owl (Strix varia). Histol. Histopathol. 1996;1(1):89-96.

59. Snedecor, G. W. and Cochran, W. G.: Statistical Methods $8^{\text {th }}$ Edn. Lowa State University Press; 1989.

60. Sprigings, E.: Measurement of the modeling parameters for a Maxiflex "B" Springboard. Intern.Journal of Sport Biomechanics. 1990;6: 325-335.

61. Ferreira, T. A. C.: contributors for a physiological and clinical histopathology in bird ophthalmology; 2015.

62. Tsugio, A.: Electron histochemical study of alkaline phosphatase activity in the pecten oculi of the chick. Graefes arch clin. Exp. Ophthalmol. 1982;219 (1):114.

63. Tsugio, A.: Effectiveness of elastase with $\mathrm{HCl}$ method for cell surface visualization. Acta. Anat. (Basel). 1984;120(3):108-111.

64. Tsugio, A. (a): Constituents of connective tissue around the capillary of chick pecten oculi. Acta. Anat. (Basel). 1985;122(4): 235-238.

65. Tsugio, A. (b): Effect of elastase on the histochemical demonstration of alkaline phosphatase activity in chick pecten. Acta. Histoche. 1985; 77 (2):193-197.

66. Tucker, R.: The surface of the pecten oculi in the pigeon. Cell Tissue Res. 1975;157 (4):457-65.

67. Venkateshan, S. and Ramesh, G.: Anatomy of the pecten and its functional correlation in domestic fowl, Ind. Journal of Animal Sci. 2006; 76(12): 1010-1013.

68. Wang, K., Yang, Y. R., Feng, Y. J. and Liang, H. D.: Morphological study of the pecten oculi from ostrich (Struthio camelus). Acta. Anat. Sinica. 2015; DOI: 10.16098/05291356.

69. Wikipedia: Elevatedalkalinephosphatase. 2017; https://en.wikipedia.org/wiki/Alkaline phosphatase

70. Wikipedia : Guinea fowl. 2018; https://en.wikipedia.org/wiki/Guineafowl.

71. Wikivet : Heterophils. 2017; http://commons.wikivet.net/images /b/b8/editing

72. Wingstrand, K. G. and Munk,O.: The pecten oculi of the pigeon with particular regard to its function. Bio. 1965;14: 1- 64.

73. Wolburg, H., Liebner, S., Reichenbach, A. and Gerhardt, H.: The pecten oculi of the chicken: A model system for vascular differentiation and barrier maturation. Inter. Rev. Cytol.; 1999;187: 111- 159. 